\title{
ASIAN NIPAH VIRUS AND THE POTENTIAL OF NEW PANDEMIC
}

\author{
Esam Bashir Yahya ${ }^{1 *}$; Amaal Mohammed Alqadhi²; Muhanad Abdullah Abdulsamad ${ }^{3}$; Abdulmutalib \\ Alabeed Allaq ${ }^{4}$
}

${ }^{1}$ School of Industrial Technology, Universiti Sains Malaysia, Penang 11800, Malaysia; ${ }^{2}$ Faculty of Medicine, El Mergab University, Al Khums, Libya; ${ }^{3}$ Dept. of Molecular Biology, Faculty of Science, Sabratha University, Sabratha, Libya; ${ }^{4}$ Faculty of applied science, Universiti Teknologi MARA, Shah Alam, Malaysia. *Corresponding author: essam912013@gmail.com

Article received 16.2.2021, Revised 13.3.2021, Accepted 19.3.2021

\begin{abstract}
Nipah virus infection is a renewable threatening stage III zoonotic disease caused high mortality rates and significant public health risks in the past two decades. Several outbreaks of the Nipah virus occurred in Malaysia, Bangladesh, India and other Asian countries, which differed in the characteristics as each outbreak results from a novel strain of the virus. The continuous change of the viral hosts, as it jumps from bats to the animal/human and vice versa, but the virus in need to adapt to the new environment and favor mutations accuracy. The recent outbreaks of the virus caused much concern worldwide due to its ease of transmission and high mortality rates. During the rapid spread and replication of Nipah virus, more mutations are likely to develop, enhancing its epidemiological patterns and increasing its pathogenicity, raising the risk for a new pandemic. This review presents the chronological development of Nipah virus outbreaks and the main differences from the originally discovered Nipah virus and the more recent strains and discussed the potential of this virus to become a new pandemic.
\end{abstract}

Keywords: Nipah Virus, zoonotic infectious disease, potential pandemic, bats.

\section{1- INTRODUCTION}

The first discovery of Nipah Virus was in Malaysia in 1998 among directly contacted people with sick pigs. The virus was able to induce acute encephalitis in humans and some animals, and it has Pteropus bats as a wildlife reservoir (Pulliam et al., 2012). During the first outbreak of the Nipah virus, $39 \%$ of 283 infected people died after a few daysafter the infection, which was confirmed using diagnostic tests. Bangladesh has also anno-unced another outbreak of Nipah Virus in 2001, many cases of infected people are reported in Bangladesh and occasionally in neighboring India. More than $70 \%$ of all the confirmed Nipah virus cases have died (Luby et al., 2009). However, Sejvar et al., (2007) reported that one-third of survived cases have permanent neurological defi-cits. Since that time, several outbreaks have been reported in many Asian countries, including China, Malaysia, India, Bangladesh and others; these outbreaks were associated with short-chain of peoples based on direct contact person-to-person or animals to peoples. Various symptoms have been reported in Nipah virus disease, including fever, constitutional symptoms, and encephalitis, be accompanied by respiratory illness (Halpin et al., 2011). Following the other short outbreaks happened, with little differences in the viral characteristics and symptoms each time, as it is an RNA virus known for their increased rate for mut-ations. In May 2018, a new outbreak of the Nipah virus was reported in India, which caused much concern its ease of transmission, unlike the pre-vious Malaysian strain of the virus (Majee et al., 2020). The World Health Organization announced that this outbreak could be a new pandemic as the virus showed increasingly high pathogenicity and contagious levels than any of the previous out-breaks. In the absence of any vaccine or effective treatment of Nipah virus, the WHO recommend raising the awareness of the risk factors and educating people in term of the measures that can be taken to reduce or even avoid Nipah virus infe-ction. The presents review, discuss the chrono-logical development and the biological character-istics of Nipah virus and its potential as new pandemic.

\section{2- Classification and characteristics of Nipah Virus}

Nipah virus is a deadly zoonotic virus that belongs to the Paramyxoviridae family of viruses and the Henipavirus genus. The virus possesses severity of the pathogenesis to human and animals, and it is classified among level 4 (BSL-4), with designated category $\mathrm{C}$ of priority pathogen, which is the highest level of biosafety pathogen classifications (Angeletti, et al., 2016). The name 'Nipah virus' originated first in Malaysia upon the first discovery of the virus, which came from Sungai Nipah area in Malaysia, where the virus was first isolates (Control \& Prevention, 1999b). Bats of the genus Pteropus have been reported to be the natural reservoir of the virus, which also reported to swept between 1998 and 1999 through numerous Malaysian piggeries and killed 1100 people (Control \& Prevention, 1999a). Nipah virus has also been cla- 
ssified as an enveloped virus with filamentous nucleocapsids; its genome consists of negative-sense single-stranded RNA of approximately $18.2 \mathrm{~kb}$. This viral genome has been studied by Wang et al., (2001) who reported that it encodes for six main structural proteins, including phosphoprotein $(\mathrm{P})$, nucleocapsid $(\mathrm{N})$, glycoprotein $(\mathrm{G})$, fusion protein $(\mathrm{F})$, matrix protein $(\mathrm{M})$ and large protein $(\mathrm{L})$. The Nipah virus's ribonucleoprotein complex is formed by the $\mathrm{N}, \mathrm{P}$ and $\mathrm{L}$ structural proteins reg-ulate the transcription and synthesis of viral RNA (Soman et al., 2020). Figure 1 presents the structure of the virus and its genome. The RNA genome is surrounded by an envelope of lipid bilayer studded with the glycoproteins $\mathrm{G}$ and $\mathrm{F}$, which attached to the structural proteins. The inner part of the viral envelope is well associated with the matrix protein $\mathrm{M}$.

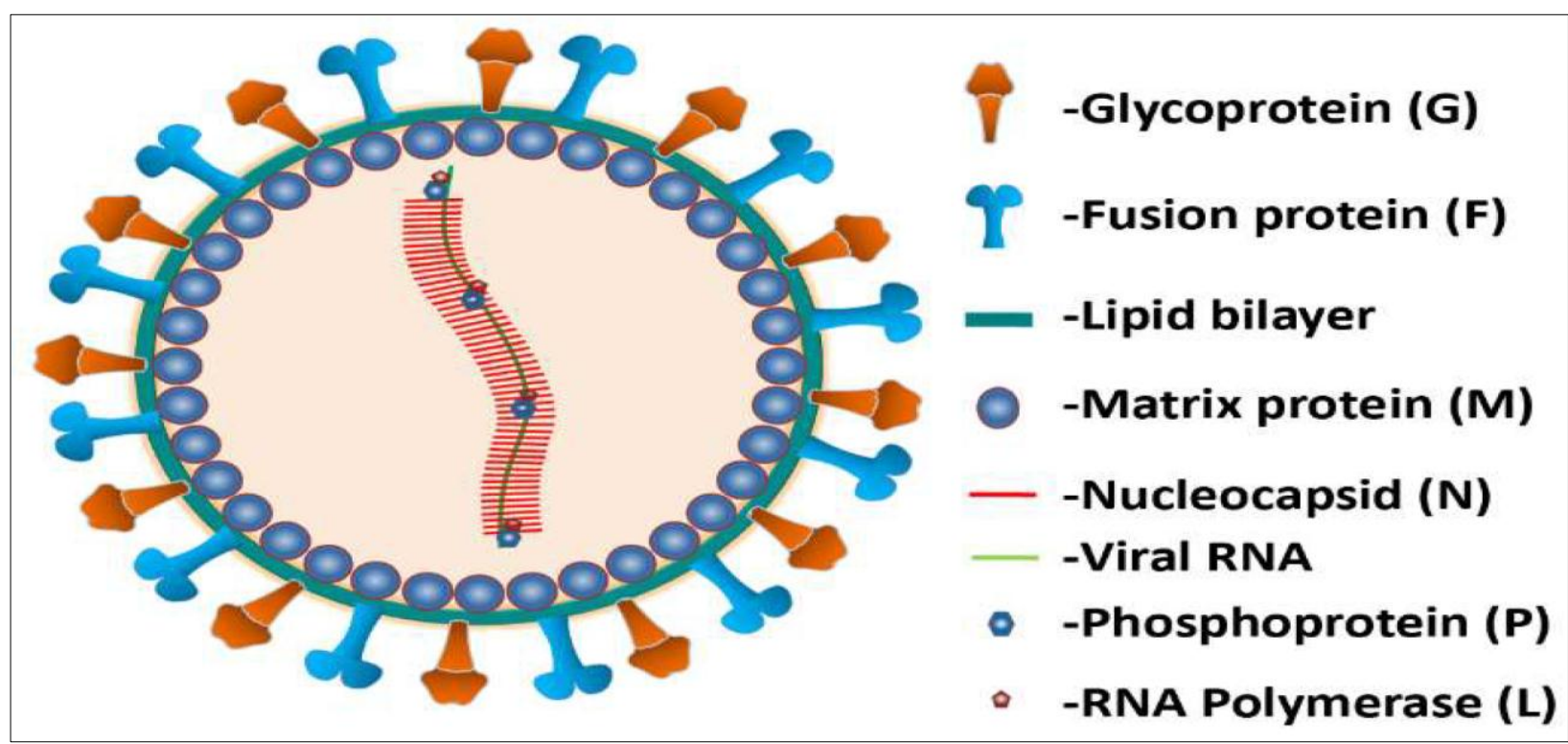

Figure 1: Schematic drawing of Nipah virus structure and the structural proteins responsible for the genome synthesis. Adapted from Soman Pilla et al. (Soman Pillai et al., 2020)

The virus's attachment and entry into the host cell have been studied by Tamin et al. (Tamin et al., 2002) who reported that it controlled by the two structural proteins: the F and G proteins, which span across the viral envelope (Yahya, Jummaat, et al., 2020). The G protein initially mediates the virus attachment to the host tissues and binds to the cellular receptors (Ephrin-B2 and -B3), while the F structural protein induces the fusion of the viral-cell membrane and facilitate the entry process of the virion (Xu, et al., 2012). A typical encephalitic syndrome characterized by paramyxovirus infection and significant pulmonary manifestations are the main feature of the first outbreak of Nipah Virus (Goh et al., 2000). A few years later, many researchers have successfully isolated the syncytium-forming virus from the cerebrospinal fluid (CSF) of infected patients and observed it under the electron microscope and observed the morphological characters as an enveloped virus with filame- ntous nucleocapsids (Goldsmith et al., 2003; Guillaume et al., 2004). The negative staining of the virus showed it as herringbone structure, as typical Paramyxoviridae family virus (Guillaume et al., 2004). Broad reservoirs and host range characterize paramyxoviruses family of viruses, and for this reason, thus they considered as an important zoonotic potential, such as Nipah and Hendra viruses originating from different types of bats (Angeletti et al., 2016; Towner et al., 2009). More than 1200 chiropteran species of bats have been identified, which are distributed worldwide, representing the most successful mammals on earth. Many viruses such as Marburg, Ebola, SARS and even COVID-19 have been identified in various species of bats in the last decades, such as Pteropus spp and fruit bats (Sun, Jia, Liang, Chen, \& Liu, 2018). The route of Nipah virus infection of from its reservoirs (bats) to humans is occurred by ingestion and consumption of viral-contaminated fruits or any food, the 
direct contact of human with infected animals including pigs, cattle and goats have been reported to cause the disease (Chattu, Kumar, Kumary, Kajal, \& David, 2018).

\section{3- Epidemiology and Pathogenesis}

The first outbreak of Nipah virus was only characterized as primarily encephalitic without documenting any human-to-human trans- mission (Goh et al., 2000). The outbreaks of Nipah virus have been reported in Malaysia, Bangladesh, Singapore, India and China; the highest mortality was found in Bangladesh, where the outbreak was typically happened during winter. Table 1 presents the list of Nipah virus outbreaks since its first discovered.

Table 1. Illustration of different outbreaks of Nipah virus in the Asian counties

\begin{tabular}{|c|c|l|c|}
\hline Year & Country & \multicolumn{1}{|c|}{ Remark } & Reference \\
\hline $\begin{array}{c}\text { September 1998 } \\
\text { to May 1999 }\end{array}$ & Malaysia & $\begin{array}{l}105 \text { deaths out of 265 cases of acute encephalitis } \\
\text { caused by the virus reported in three different } \\
\text { states of the country. }\end{array}$ & (Looi \& Chua, 2007) \\
\hline $\begin{array}{c}\text { January and } \\
\text { February 2001 }\end{array}$ & India & $\begin{array}{l}\text { Sixty-six cases reported with a 74\% mortality rate, } \\
\text { and the first evidence of person-to-person } \\
\text { transmission. }\end{array}$ & (Chadha et al., 2006) \\
\hline 2001 and 2003 & Bangladesh & $\begin{array}{l}\text { Twenty-five cases were reported with 17 fatalities; } \\
\text { the transmission also confirmed from person-to- } \\
\text { person. }\end{array}$ & (Hsu et al., 2004) \\
\hline January to April & Bangladesh & $\begin{array}{l}\text { Seventy-eight cases with 41 fatalities, most of } \\
\text { them involved close contact with an infected } \\
\text { person with Nipah virus. Acute respiratory distress } \\
\text { syndrome observed. }\end{array}$ & (Luby, 2013) \\
\hline January 2005 & Bangladesh & $\begin{array}{l}\text { Twelve cases with 11 fatalities, infection caused } \\
\text { from drinking date palm juice, which was } \\
\text { contaminated by fruit bat. }\end{array}$ & (Icddr, 2005) \\
\hline February to May, & India & $\begin{array}{l}\text { Fifty cases were reported with 5 fatalities, resulted } \\
\text { from Nipah virus encephalitis with person-to- } \\
\text { person transmission. }\end{array}$ & (Gurley et al., 2007) \\
\hline February 2008 & Bangladesh & Nine cases were reported, with eight fatalities. & (Chowdhury et al., 2014) \\
\hline January 2010 & Bangladesh & Eight cases were reported, with seven fatalities. & (ICDDR, 2010) \\
\hline February 2011 & Bangladesh & $\begin{array}{l}\text { Dozens of cases with 21 fatalities of } \\
\text { schoolchildren. }\end{array}$ & $\begin{array}{l}\text { Twenty-three cases with 21 fatalities were reported } \\
\text { and antivirals-based treatment was initiated. }\end{array}$ \\
\hline
\end{tabular}

Various studies revealed that the transmission of Nipah virus from person to person is rare, which changed after few years as described by Luby et al. (Luby et al., 2009). They reported that only $7 \%$ of Nipah patients in Bangladesh transmit the infection, making the possibility of person-to-person Nipah transmission mostly occur as individual cases after one or two weeks later. However, most outbreaks of the virus have been confined to India and Bangladesh, taking fruit bats (Pteropodidae family) as the natural reservoir (Gurley et al., 2017). These reservoirs ere able to contaminate the fruits and infect humans and/or animals. Nipah virus believed to have broad species tropism, with the ability to infect many domestic animals such as horses, pigs and cows, increasing its chances for zoonotic transmission from intermediate hosts (Chakraborty et al., 2016; Luby \& Gurley, 2012). Various transmission have been reported, including direct transmission from the reservoirs, from any infected animals, from infected humans or contaminated food such as fruits. Figure 2 presents a summary of these methods of transmission. 


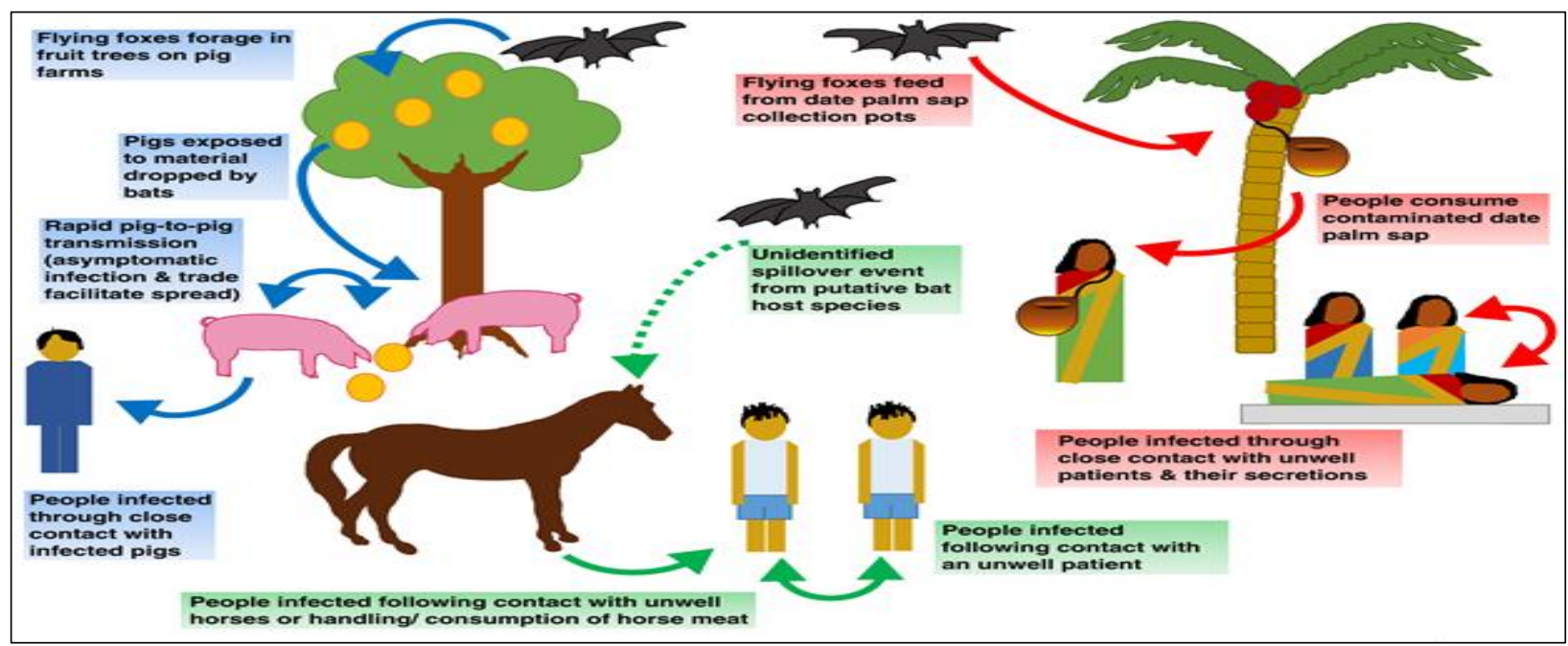

Figure 2: Illustration of transmitting methods Nipah virus in the original Malaysian (blue arrows) and the recent strains (red and green arrows). Adapted from Clayton, B. A. (Bronwyn Anne Clayton, 2017)

\section{4- A potential new pandemic of Nipah virus}

Nipah virus is one of the RNA viruses characterizedby their high rate of spontaneous mutations (same as the current COVID-19) than any other virus (Lo et al., 2020; Yahya \& Alqadhi, 2021). This character gives the virus the ability to gain potential adaptation to new environments, infection of new hosts, develop new virulence factors, avoid our immune defenses and/or accelerate its transmissibility and contagious spreading. Measles virus evolved from mutation between the 11th and 12th century from the progenitor rinderpest, a paramyxovirus that caused one of the top viral outbreaks (Furuse, Suzuki, \& Oshitani, 2010). Lo et al. (Lo et al., 2012) revealed substantial genetic heterogeneity in the strains isolated from Bangladesh of Nipah virus. Interestingly, only one strain was isolated and identified the virus in Malaysia throughout the outbreak (AbuBakar et al., 2004; Chua et al., 2000). Nipah virus infections have also been attached with the origin of Pteropus bats, which have a wide geographical range all over the Asian countries (Hsu et al., 2004; Wacharapluesadee et al., 2010). The variation of environments, the hosts, may enhance and accelerate the mutation rate of RNA viruses, leading to their development in the current outbreaks (Welch et al., 2020; Yahya, Alfallous, Wali, Hameid, \& Zwaid, 2020). Personto-person transmission is another difference between the two strains of Bangladesh and Malaysia, as it was rare in Malaysia compared to more than the third of cases among Bangladesh's strain, which can be related to the phenotypic heterogeneity of Nipah virus (Luby, 2013). The infectivity and antigenic variability of Nipah virus was reported to be associated with virus genetic polymorphisms $(\mathrm{Li}$ et al., 2020). Nipah virus continuously changes the hosts, as it jumps from the bat to the animal/human and vice versa, making it face new selection pressures as the host environment changes. In particular, the Nipah virus's antigenic variability is critical to escape different immune response in all the infected hosts, thus more likely the virus develop new mutations to adapt with the environment. The recent confirmation of the viral transmission suggests ferrets inoculated with a Nipah virus strain from Bangladesh showed ten times higher virus shed in the saliva compared with those inoculated with the Malaysian strain (Bronwyn A Clayton et al., 2012). The adaptation of Nipah virus to humans' body probably depends on the potentiating mutations stepwise accumulation that favor and enhance the emergence adaptation to the new environment. A similar mechanism of adaptation in other viruses such as seasonal influenza and COVI$\mathrm{D}$-19. Li et al. (Li et al., 2020) recently identified several amino acid changes among two Nipah virus lineages, resulting from the adaptation to affect receptor binding and accelerate the transmission, suggesting the presence of serious Nipah virus pandemic potential. The historical devastation of Nipah virus as stage III zoonotic disease, its high case fatality rate and its ability for rapid mutation to adapt with different environments should raise the concerns for the potential pandemic risk of Nipah virus.

\section{5- Conclusion}

Nipah virus is a highly pathogenic stage III zoonotic disease virus that caused several outbreaks in the past two decades, which had different characteristics resulted from the spontaneous development of the virus. The variation of viral hosts from bats to animals and human make the virus face pressure and exposed to different hosts environ- 
ments, which accelerate its mutation. These mutations have led to increased pathogenicity and spreading rate, suggesting serious Nipah virus pandemic potential in the following years. This review delivered an overview of Nipah virus outbreaks' chronological development and highlighted the potential of the new Nipah virus pandemic.

\section{REFERENCES}

AbuBakar, S., Chang, L.-Y., Ali, A.M., Sharifah, S., Yusoff, K. and Zamrod, Z., Isolation and molecular identification of Nipah virus from pigs. Emerging Infectious Diseases 10(12): 2228 (2004). (2016).

Angeletti, S., Presti, A.L., Cella, E. and Ciccozzi, M., Molecular epidemiology and phylogeny of Nipah virus infection: A mini review. Asian Pacific Journal of Tropical Medicine 9(7): 630-634 (2016).

Chadha, M.S., Comer, J.A., Lowe, L., Rota, P.A., Rollin, P.E., Bellini, W.J., Thomas G.K. and Mishra, A. C., Nipah virus-associated encephalitis outbreak, Siliguri, India. Emerging infectious diseases 12 (2): 235 (2006)

Chakraborty, A., Sazzad, H., Hossain, M., Islam, M., Parveen, S., Husain, M., . Rollin, P. Evolving epidemiology of Nipah virus infection in Bangladesh: evidence from outbreaks during 2010-2011. Epidemiology \& Infection, 144(2): 371-380 (2016).

Chattu, V.K., Kumar, R., Kumary, S., Kajal, F. and David, J.K, Nipah virus epidemic in southern India and emphasizing "One Health" approach to ensure global health security. Journal of family medicine and primary care 7(2): 275 (2018)

Chowdhury, S., Khan, S. U., Crameri, G., Epstein, J.H., Broder, C.C., Islam, A., Wang, L.-F., Serological evidence of henipavirus exposure in cattle, goats and pigs in Bangladesh. PLoS Negl Trop Dis, 8(11): e3302 (2014).

Chua, K., Bellini, W., Rota, P., Harcourt, B., Tamin, A., Lam, S., ... Shieh, W.-J., Nipah virus: a recently emergent deadly paramyxovirus. Science 288(5470): 1432-1435 (2000).

Clayton, B.A. Nipah virus: transmission of a zoonotic paramyxovirus. Current opinion in virolog 22: 97-104 (2017).

Clayton, B.A., Middleton, D., Bergfeld, J., Haining, J., Arkinstall, R., Wang, L. and Marsh, G.A., Transmission routes for Nipah virus from Malaysia and Bangladesh. Emerging infectious diseases 18(12): 1983 (2012).
Control, C.f.D. and Prevention, Outbreak of Hendra-like virus--Malaysia and Singapore, 1998-1999. MMWR. Morbidity and mortality weekly report 48(13): 265-269 (1999a).

Control, C.f.D. and Prevention, Update: outbreak of Nipah virus--Malaysia and Singapore, 1999. MMWR. Morbidity and mortality weekly report 48(16): 335-337 (1999b).

Furuse, Y., Suzuki, A. and Oshitani, H., Origin of measles virus: divergence from rinderpest virus between the 11 th and 12 th centuries. Virology journal 7(1): 1-4 (2010).

Goh, K.J., Tan, C.T., Chew, N.K., Tan, P.S.K., Kamarulzaman, A., Sarji, S. A., . . Lam, S. K., Clinical features of Nipah virus encephalitis among pig farmers in Malaysia. New England Journal of Medicine 342(17): 1229-1235 (2000).

Goldsmith, C.S., Whistler, T., Rollin, P.E., Ksiazek, T. G., Rota, P. A., Bellini, W. J., . . . Zaki, S. R. (2003). Elucidation of Nipah virus morphogenesis and replication using ultrastructural and molecular approaches. Virus research, 92(1), 89-98.

Guillaume, V., Lefeuvre, A., Faure, C., Marianneau, P., Buckland, R., Lam, S. K., . . . Deubel, V. (2004). Specific detection of Nipah virus using real-time RT-PCR (TaqMan). Journal of virological methods, 120(2), 229237.

Gurley, E.S., Hegde, S.T., Hossain, K., Sazzad, H. M., Hossain, M.J., Rahman, M., . Epstein, J. H., Convergence of humans, bats, trees, and culture in Nipah virus transmission, Bangladesh. Emerging infectious diseases 23(9): 1446. (2017).

Gurley, E.S., Montgomery, J.M., Hossain, M.J., Bell, M., Azad, A.K., Islam, MR., . Rota, P.A., Person-to-person transmission of Nipah virus in a Bangladeshi community. Emerging infectious diseases 13(7): 1031 (2007).

Halpin, K., Hyatt, A.D., Fogarty, R., Middleton, D., Bingham, J., Epstein, J.H., . . . Field, H.E., Pteropid bats are confirmed as the reservoir hosts of henipaviruses: a comprehensive experimental study of virus transmission. The American Journal of Tropical Medicine and Hygien, 85(5): 946-951 (2011).

Hsu, V.P., Hossain, M.J., Parashar, U.D., Ali, M. M., Ksiazek, T.G., Kuzmin, I., . Breiman, R.F., Nipah virus encephalitis reemergence, Bangladesh. Emerging infectious diseases 10(12): 2082 (2004).

Icddr, B., Nipah virus outbreak from date palm juice. Health and Science Bulletin 3(4): 1-5 (2005). 
ICDDR, B., Nipah outbreak in Faridpur District, Bangladesh, 2010. HSB (Health Science Bulletin) 8(2): (2010).

Li, K., Yan, S., Wang, N., He, W., Guan, H., He, C., . . . Emergence and adaptive evolution of Nipah virus. Transboundary and emerging diseases 67(1): 121-132 Ye, R. (2020).

Lo, M.K., Lowe, L., Hummel, K.B., Sazzad, H.M., Gurley, E.S., Hossain, M.J., . . . Rollin, P.E. Characterization of Nipah virus from outbreaks in Bangladesh, 2008-2010. Emerging infectious diseases 18(2): 248 (2012).

Lo, M.K., Spengler, J.R., Welch, S.R., Harmon, J. R., Coleman-McCray, J.D., Scholte, F.E., . . . Weissman, D., Evaluation of a single-dose nucleoside-modified messenger RNA vaccine encoding Hendra virus-soluble glycoprotein against lethal Nipah virus challenge in Syrian hamsters. The Journal of infectious diseases 221(Supplement_4): S493-S498 (2020).

Looi, L.M. and Chua, K.B., Lessons from the Nipah virus outbreak in Malaysia. Malaysian Journal of Patholog, 29(2): 63-67 (2007).

Luby, S.P., The pandemic potential of Nipah virus. Antiviral research 100(1): 38-43 (2013).

Luby, S.P. and Gurley, E.S., Epidemiology of henipavirus disease in humans. Henipavirus Pp. 25-40 (2012).

Luby, S.P., Hossain, M.J., Gurley, E.S., Ahmed, B.-N., Banu, S., Khan, S. U., . Comer, J.A., Recu-rrent zoonotic transmission of Nipah virus into humans, Bangladesh, 2001-2007. Emerging infectious diseases 15(8): 1229 (2009).

Majee, P., Mishra, S.K., Pandya, N., Shankar, U., Pasadi, S., Muniyappa, K., . . Kumar, A., Identification and characterization of two conserved G-quadruplex forming motifs in the Nipah virus genome and their interaction with G-quadruplex specific ligands. Scientific reports 10(1): 1-12 (2020).

Pulliam, J. R., Epstein, J. H., Dushoff, J., Rahman, S. A., Bunning, M., Jamaluddin, A. A., . . . Daszak, P., Agricultural intensification, priming for persistence and the emergence of Nipah virus: a lethal bat-borne zoonosis. Journal of the Royal Society Interface 9(66): 89-101 (2012).

Sejvar, J.J., Hossain, J., Saha, S.K., Gurley, E.S., Banu, S., Hamadani, J.D., . . Mollah, A.H., Long-term neurological and functional outcome in Nipah virus infection. Annals of Neurology: Official Journal of the American Neurological Association and the Child Neurology Society 62(3): 235-242 (2007).
Soman Pillai, V., Krishna, G. and Valiya Veettil, M., Nipah Virus: Past Outbreaks and Future Containment. Viruses 12(4): 465 (2020).

Sun, B., Jia, L., Liang, B., Chen, Q. and Liu, D., Phylogeography, transmission, and viral proteins of Nipah virus. Virologica Sinica 33(5): 385-393 (2018).

Towner, J.S., Amman, B.R., Sealy, T.K., Carroll, S. A.R., Comer, J.A., Kemp, A., . hristova, M.L., Isolation of genetically diverse Marburg viruses from Egyptian fruit bats. PLoS Pathog 5(7): e1000536 (2009).

Verma, M.K., Verma, P., Singh, S., Gaur, P., Siddiqui, A.H. and Pandey, S., Nipah VirusInfectious Agent: An Overview. Int. J. Life. Sci. Scienti. Res. eISSN 2455(1716): 1716 (2018)..

Wacharapluesadee, S., Boongird, K., Wanghongsa, S., Ratanasetyuth, N., Supavonwong, P., Saengsen, D., . . . Hemachudha, T., A longitudinal study of the prevalence of Nipah virus in Pteropus lylei bats in Thailand: evidence for seasonal preference in disease transmission. Vector-Borne and Zoonotic Diseases 10(2): 183-190 (2010).

Wang, L.-F., Harcourt, B. H., Yu, M., Tamin, A., Rota, P. A., Bellini, W. J. and Eaton, B. T., Molecular biology of Hendra and Nipah viruses. Microbes and infection 3(4): 279-287 (2001).

Welch, S.R., Tilston, N.L., Lo, M.K., Whitmer, S. L., Harmon, J.R., Scholte, F.E., . . . Spiropoulou, C. F., Inhibition of Nipah virus by defective interfering particles. The Journal of infectious diseases 221(Supplement_4): S460S470 (2020).

Xu, K., Broder, C.C. and Nikolov, D.B., Ephrin$B 2$ and ephrin-B3 as functional henipavirus receptors. Paper presented at the Seminars in cell \& developmental biology (2020).

Yahya, E.B., Alfallous, K.A., Wali, A., Hameid, S. and Zwaid, H., Growth rate and antibiotic sensitivity effect of some natural and petroleum based materials on Staphylococcus aureus. International Journal for Research in Applied Sciences and Biotechnology 7(5): 7-11 (2020).

Yahya, E. B. and Alqadhi, A.M., Recent trends in cancer therapy: A review on the current state of gene delivery. Life Sciences 119087 (2021).

Yahya, E.B., Jummaat, F., Amirul, A., Adnan, A., Olaiya, N., Abdullah, C., . . Khalil, H., A review on revolutionary natural biopolymerbased aerogels for antibacterial delivery. Antibiotics 9(10): 648 (2020). 